\title{
Effect of Seasonal Variation on the Physicochemical Characteristics of Borehole Water in Ogbaru Communities, Anambra State, Nigeria
}

\author{
Onuorah Samuel*, Igwemadu Nkiruka, Odibo Frederick \\ Department of Applied Microbiology and Brewing, Nnamdi Azikiwe University, Nigeria
}

Copyright $\mathrm{C} 2019$ by authors, all rights reserved. Authors agree that this article remains permanently open access under the terms of the Creative Commons Attribution License 4.0 International License

\begin{abstract}
Analysis of water boreholes in Ogbaru Communities, Anambra State was carried out during the dry and wet seasons to determine the effect of seasonal variation on their physicochemical characteristics. Fifteen drinking water boreholes were sampled from different locations in the communities. The $\mathrm{pH}$ values were in the range of $3.4-8.3$; temperature, $28-29^{\circ} \mathrm{C}$; electrical conductivity, $15-238 \mathrm{us} / \mathrm{cm}$; total suspended solids, $0.00-0.25 \mathrm{mg} / 1$; total alkalinity, $4.0-27.0 \mathrm{mg} / 1$; total acidity, $2.5-7.5 \mathrm{mg} / \mathrm{l}$; total hardness, $30.0-84.0 \mathrm{mg} / 1$; calcium hardness, 0.6-3.4mg/1; magnesium hardness, $6.8-18.0 \mathrm{mg} / 1$; total chlorides, $7.3-66.5 \mathrm{mg} / \mathrm{l}$; sulphates, $0.00-0.04 \mathrm{mg} / \mathrm{l}$; cadmium, $0.01-0.32 \mathrm{mg} / 1$; lead, $0.00-0.08 \mathrm{mg} / 1$; arsenic, $0.00-0.04 \mathrm{mg} / 1$ and iron, $0.00-0.05 \mathrm{mg} / \mathrm{l}$ during the dry season while the $\mathrm{pH}$ ranged from 4.8 to 8.5 ; temperature, $25-28^{0} \mathrm{C}$; electrical conductivity, $41-910 \mathrm{us} / \mathrm{cm}$; total suspended solids, $\quad 0.03-2.01 \mathrm{mg} / \mathrm{l}$; total alkalinity, $12.0-40.0 \mathrm{mg} / 1$; total acidity, $5.0-22.5 \mathrm{mg} / 1$; total hardness, $45.0-94.0 \mathrm{mg} / \mathrm{l}$; calcium hardness, $1.8-10.4 \mathrm{mg} / \mathrm{l}$; magnesium hardness, $10.3-21.7 \mathrm{mg} / 1$; total chlorides, $52.8-96.6 \mathrm{mg} / 1$; sulphates, $0.00-0.06 \mathrm{mg} / 1$, cadmium, $0.03-0.34 \mathrm{mg} / 1$; lead, $0.01-0.20 \mathrm{mg} / 1$; arsenic, $0.00-0.04 \mathrm{mg} / 1$ and iron, $0.02-0.08 \mathrm{mg} / 1$ during the wet season. These results showed that the season had pronounced effect on the physicochemical characteristics of the water from the boreholes sampled. Some of the boreholes studied did not comply with the World Health Organization standards for potable water in terms of $\mathrm{pH}$, total acidity, cadmium, lead and arsenic and require adequate treatment before drinking to safeguard the health of the users.
\end{abstract}

Keywords Seasonal Variation, Physicochemical, Characteristics, Borehole, Water, Ogbaru Communities

\section{Introduction}

Unsafe water is a global public health threat, placing persons at risk to a host of diarrheal and other diseases as well as chemical intoxication [1]. It has devastating effect on young children in developing world. Each year, more than two million persons, mostly children less than five years of age die of diarrheal disease [2].Ground water is a major source of drinking water in both urban and rural areas. In Nigeria, ground water contamination is one of the least recognized environmental problems because its problems are not readily detected and pathways for contamination are not as noticeable as those affecting surface water [3].

Ground water pollution occurs widely from a variety of anthropogenic sources such as waste disposal facilities, industrial pollution, agricultural practices and atmospheric fallout. Changes in land usage, such as the clearing of vegetation, over-abstraction of groundwater or excavation below the water table can also contribute significantly to groundwater pollution [4].Pollution is usually associated with the presence of toxic substances or energy in quantity more than what can be attenuated by the environment on the basis of natural degradative changes. Drilling records showed that $20 \%$ of wells drilled for domestic water supplies contain high levels of manganese and iron above the WHO permissible limits of $0.01 \mathrm{mg} / 1$ and $0.3 \mathrm{mg} / 1$ for manganese and iron respectively [5].

Many agencies have contributed to the provision of water to the rural population through borehole drilling. Generally, the mode of operation of the different agencies results in different types of boreholes being drilled. As a result, some of these boreholes breakdown easily and become disused while others have been found to be polluted by iron, making their use extremely limited [6].Ogbaru communities have several boreholes which have been in use for several years. Most of them have been scarcely maintained or rehabilitated since they were drilled. It is therefore imperative that the water from such boreholes must be analysed during the dry and wet seasons to determine the effect of seasonal variation on their physicochemical characteristics, which is the aim of this study. 


\section{Materials and Methods}

\subsection{Study Area}

The study area is Ogbaru Communities in Ogbaru Local Government Area of Anambra State of Nigeria.

\subsection{Samples Collection}

Samples were collected from fifteen drinking water boreholes located within the study area.The locations were

a. Odunze Street Atani

b. AbiriboseAtani

c. UjadimegwuAtani

d. Ochuche

e. Akili-Ozizor

f. Cathedral Road Atani

g. UmunduOhita

h. Odekpe

i. IyiowaOdekpe

j. OkotiOdekpe

k. OkpotunoOdekpe

1. Atani Road Okoti

m. Okpoko

n. Imeogbe

o. AnibuezeOdekpe

Each of the samples was collected in two-litre plastic containers. The containers were first of all washed with detergent and rinsed severally with the water samples from the respective boreholes before collection. The temperature and $\mathrm{pH}$ values of the samples were taken at the site of collection. The samples were collected from each borehole in triplicates during the dry (January - March 2018) and wet (May - July 2018) seasons.

\subsection{Determination of the Physical Characteristics}

The physical characteristics of the borehole water samples were determined as described by Onuorah et al.[7].

\subsubsection{Determination of Temperature}

The temperature was measured at the point of collection using a thermometer. The thermometer was immersed vertically into the samples. It was allowed to stand till the temperature reading became stable and the value was taken and recorded.

\subsubsection{Determination of $\mathrm{pH}$}

The $\mathrm{pH}$ was determined using a $\mathrm{pH}$ meter (JENWAY). The instrument was standardized using $\mathrm{p}^{\mathrm{H}}$ buffers 4.0 and 7.0. The water sample was introduced into a beaker and the meter was switched on and allowed to stabilize before being lowered into the beaker. The $\mathrm{p}^{\mathrm{H}}$ value was recorded when the meter reading stabilized.

\subsubsection{Determination of Electrical Conductivity (EC)}

The electrical conductivity was determined with Aquapro digital water conductivity meter. The water sample was introduced into a beaker and the meter was switched on and allowed to stabilize. The electrode was thereafter immersed into the sample and the value was recorded when the meter reading became stable.

\subsubsection{Determination of Total Suspended Solids (TSS)}

Fifty milliliters of the water sample were filtered through a pre weighed glass fiber filter.The filter was heated to constant mass at $105^{\circ} \mathrm{C}$ and then weighed.The mass increase divided by the water volume filtered is equal to the total suspended solids in $\mathrm{mg} / \mathrm{l}$.

Total suspended solids $(\mathrm{mg} / \mathrm{l})=(\mathrm{A}-\mathrm{B}) \times 1000$

$\mathrm{ml}$ sample

$\mathrm{A}=$ weight of filter + dried residue

$\mathrm{B}=$ weight of filter

\subsection{Determination of Chemical Characteristics}

These were also determined as described by Onuorah et al. [7].

\subsubsection{Determination of Total Alkalinity}

One hundred milliliters of the water sample were introduced into a $250 \mathrm{ml}$ conical flask. Two drops of bromocresol green solution were added as the indicator and the mixture was titrated with $0.02 \mathrm{~N}$ sulphuric acid till a colour change from green to yellow was observed and the titre value was recorded.

\subsubsection{Determination of Total Acidity}

One hundred milliliters of the water sample were introduced into a $250 \mathrm{ml}$ conical flask. A drop of a mixed solution of bromothymol blue and phenolphthalein was added and the mixture was titrated with barium hydroxide till a colour change from yellow to red was observed. The titre value was thereafter recorded.

\subsubsection{Determination of Total Hardness}

One hundred milliliters of the water sample were introduced into a $250 \mathrm{ml}$ conical flask. $1 \mathrm{ml}$ of buffer $(\mathrm{pH}$ 10.0), $2 \mathrm{ml}$ ofsulphuric acid and $0.2 \mathrm{ml}$ of Eriochrome Black $\mathrm{T}$ indicator were added and the mixture was titrated with Ethylenediaminetetraacetic acid (EDTA) till a blue colour was observed and the titre value was recorded.

\subsubsection{Determination of Calcium Hardness}

One hundred milliliters of the water sample were introduced into a $250 \mathrm{ml}$ conical flask. $0.5 \mathrm{ml}$ of a mixed solution of murexide and sodium chloride were added. One milliliter of sodium hydroxide solution was also introduced and the mixture was titrated with EDTA solution till a change of colour to purple was observed. The titre value was thereafter recorded. 


\subsubsection{Determination of Magnesium Hardness}

This was determined from the values of the total hardness and calcium hardness.

Magnesium Hardness = Total hardness - calcium hardness $\mathrm{x} 0.234$ where $0.234=$ constant.

\subsubsection{Determination of Total Chlorides}

One hundred milliliters of the water sample were introduced into a $250 \mathrm{ml}$ conical flask. $1 \mathrm{ml}$ of potassium dichromate indicator solution was added and the mixture was titrated with silver nitrate solution till a colour change from yellow to reddish brown was observed. The titre value was thereafter recorded.

\subsubsection{Determination of Sulphates}

One hundred milliliters of the water sample were passed through a filter paper into a conical flask and $10 \mathrm{ml}$ of barium nitrate were introduced into it. A new filter paper was weighed and the mixture was passed through it. The new filter paper was thereafter oven dried at $105^{\circ} \mathrm{C}$ for 30 seconds and the weight recorded.

Sulphates $=\underline{(\mathrm{A}-\mathrm{B}) \times 1000}$

Volume of sample

$A=$ weight of filter paper + suspended particles

$\mathrm{B}=$ weight of filter paper

$1000=$ one litre

\subsection{Determination of Heavy Metals}

The heavy metals, cadmium, lead, arsenic and iron were determined by atomic absorption spectrometry as described by APHA [8].

The water sample was thoroughly mixed by shaking and one hundred milliliters of it were introduced into a $250 \mathrm{ml}$ beaker. The sample was digested with concentrated nitric acid and thereafter filtered into a sample bottle. The water sample was aspirated into the oxidizing air-acetylene flame. When the aqueous sample was aspirated, the absorbance was read using the Varian AA240 Atomic Absorption Spectrophotometer and the value was recorded.

\subsection{Statistical Analysis}

The data obtained for the physical, chemical and heavy metals characteristics during both the dry and wet seasons were subjected to correlation analysis using 1BM SPSS version 20. The critical values were determined using t-distribution table.

\section{Results}

The physical characteristics investigated in the borehole water samples in Ogbaru communities during the dry season are presented in Table 1 . The $\mathrm{pH}$ values were 3.4-8.3, temperature, $28-29^{0} \mathrm{C}$; electrical conductivity, $15-238, \mathrm{us} / \mathrm{cm}$ and total suspended solids, $0.00-0.25 \mathrm{mg} / \mathrm{l}$.

Table 1. Physical characteristics investigated in the borehole water samples in Ogbaru Communities during the dry season

\begin{tabular}{|c|c|c|c|c|}
\hline $\begin{array}{c}\text { Borehole } \\
\text { location }\end{array}$ & $\mathbf{p H}$ & $\mathbf{T e m p}\left({ }^{\mathbf{0}} \mathbf{C}\right)$ & $\mathbf{E C}(\mathbf{u s} / \mathbf{c m})$ & $\begin{array}{c}\text { TSS } \\
(\mathbf{m g} / \mathbf{l})\end{array}$ \\
\hline $\begin{array}{c}\text { Odunze Street } \\
\text { Atani }\end{array}$ & 8.3 & 28 & 109 & 0.00 \\
\hline AbiriboseAtani & 6.5 & 28 & 56 & 0.01 \\
\hline UjadimegwuAtani & 6.6 & 29 & 52 & 0.01 \\
\hline Ochuche & 6.5 & 29 & 24 & 0.00 \\
\hline Akili-Ozizor & 7.5 & 29 & 22 & 0.01 \\
\hline Cathedral Road & 4.6 & 29 & 104 & 0.02 \\
\hline Atani & 7.0 & 29 & 41 & 0.02 \\
\hline UmunduOhita & 7.1 & 29 & 81 & 0.00 \\
\hline Odekpe & 6.7 & 29 & 77 & 0.02 \\
\hline Iyiowa & 6.7 & 29 & 238 & 0.01 \\
\hline OkotiOdekpe & 8.0 & 29 & 232 & 0.16 \\
\hline OkpotunoOdekpe & 3.4 & 29 & 41 & 0.03 \\
\hline Atani Road Okoti & 4.6 & 29 & 21 & 0.25 \\
\hline Okpoko & 7.5 & 29 & 15 & 0.14 \\
\hline Imeogbe & 6.6 & 29 & 168 & 0.23 \\
\hline AnibuezeOdekpe & $6.5-8.5$ & $25-40$ & 1000 & 30 \\
\hline WHO Standard & 3.6 & & 29 \\
\hline
\end{tabular}

Temp $=$ Temperature

$\mathrm{EC}=$ Electrical Conductivity

TSS $=$ Total Suspended Solids

The physical characteristics investigated in the borehole water samples in Ogbaru Communities during the wet season are shown in Table 2. The $\mathrm{pH}$ ranged from 4.8 to 8.5; temperature, $\quad 25-28^{\circ} \mathrm{C}$; electrical conductivity, $41-910 \mathrm{us} / \mathrm{cm}$ and total suspended solids, $0.03-2.01 \mathrm{mg} / 1$.

Table 3 showed the chemical characteristics investigated in the borehole water samples in Ogbaru communities during the dry season. The total alkalinity values were 4.0-27.0mg/l; total acidity, $2.5-7.5 \mathrm{mg} / 1$; total hardness, 30.0-84.0mg/1; calcium hardness, 0.6-3.4mg/1; magnesium hardness, $6.8-18.0 \mathrm{mg} / 1$; total chlorides, $7.3-66.5 \mathrm{mg} / 1$ and sulphates, $0.00-0.04 \mathrm{mg} / \mathrm{l}$. 

in Ogbaru Communities, Anambra State, Nigeria

Table 2. Physical characteristics investigated in the borehole water samples in Ogbaru Communities during the wet season

\begin{tabular}{|c|c|c|c|c|}
\hline Borehole location & pH & $\operatorname{Temp}\left({ }^{0} \mathrm{C}\right)$ & EC(us/cm) & TSS (mg/l) \\
\hline Odunze Street Atani & 8.5 & 26 & 201 & 0.12 \\
\hline AbiriboseAtani & 7.7 & 26 & 132 & 0.41 \\
\hline UjadimegwuAtani & 7.3 & 27 & 116 & 0.03 \\
\hline Ochuche & 7.1 & 25 & 344 & 0.24 \\
\hline Akili-Ozizor & 8.2 & 25 & 910 & 0.29 \\
\hline Cathedral Road Atani & 5.6 & 27 & 292 & 0.20 \\
\hline UmunduOhita & 8.4 & 27 & 495 & 1.60 \\
\hline Odekpe & 7.7 & 25 & 85 & 0.10 \\
\hline Iyiowa & 7.7 & 25 & 461 & 0.22 \\
\hline OkotiOdekpe & 7.8 & 27 & 348 & 0.13 \\
\hline OkpotunoOdekpe & 8.3 & 28 & 520 & 1.02 \\
\hline Atani Road Okoti & 7.3 & 28 & 85 & 0.11 \\
\hline Okpoko & 4.8 & 27 & 41 & 0.65 \\
\hline Imeogbe & 7.6 & 27 & 53 & 1.10 \\
\hline AnibuezeOdekpe & 7.4 & 28 & 170 & 2.01 \\
\hline WHO Standard & $6.5-8.5$ & $25-40$ & 1000 & 30 \\
\hline
\end{tabular}

Temp $=$ Temperature

$\mathrm{EC}=$ Electrical Conductivity

TSS $=$ Total Suspended Solids

Table 3. Chemical characteristics investigated in the borehole water samples in Ogbaru Communities during the dry season

\begin{tabular}{|c|c|c|c|c|c|c|c|}
\hline Borehole location & $\begin{array}{c}\text { Total } \\
\text { Alkalinity } \\
(\mathbf{m g} / \mathbf{l})\end{array}$ & $\begin{array}{c}\text { Total } \\
\text { Acidity } \\
(\mathbf{m g} / \mathbf{l})\end{array}$ & $\begin{array}{c}\text { Total } \\
\text { Hardness } \\
(\mathbf{m g} / \mathbf{l})\end{array}$ & $\begin{array}{c}\text { Calcium } \\
\text { Hardness } \\
(\mathbf{m g} / \mathbf{l})\end{array}$ & $\begin{array}{c}\text { Magnesium } \\
\text { Hardness } \\
(\mathbf{m g} / \mathbf{l})\end{array}$ & $\begin{array}{c}\text { Total } \\
\text { Chlorides } \\
(\mathbf{m g} / \mathbf{l})\end{array}$ & $\begin{array}{c}\text { Sulphates } \\
(\mathbf{m g} / \mathbf{l})\end{array}$ \\
\hline Odunze Street Atani & 8.0 & 7.5 & 30.0 & 1.6 & 6.8 & 27.3 & 0.02 \\
\hline AbiriboseAtani & 8.0 & 5.1 & 40.0 & 1.6 & 9.2 & 20.0 & 0.02 \\
\hline UjadimegwuAtani & 14.0 & 5.7 & 45.0 & 1.6 & 15.2 & 7.3 & 0.01 \\
\hline Ochuche & 10.0 & 5.6 & 37.0 & 1.4 & 8.5 & 20.0 & 0.03 \\
\hline Akili-Ozizor & 14.5 & 5.1 & 51.0 & 1.0 & 12.0 & 21.8 & 0.00 \\
\hline Cathedral Road Atani & 10.0 & 5.0 & 64.0 & 2.8 & 14.7 & 49.2 & 0.04 \\
\hline UmunduOhita & 27.0 & 5.0 & 84.0 & 3.4 & 18.0 & 25.5 & 0.00 \\
\hline Odekpe & 17.0 & 6.3 & 72.0 & 2.0 & 16.8 & 43.7 & 0.01 \\
\hline Iyiowa & 14.0 & 2.5 & 36.0 & 2.2 & 7.9 & 66.5 & 0.00 \\
\hline OkotiOdekpe & 12.0 & 5.0 & 35.0 & 0.6 & 8.0 & 27.3 & 0.00 \\
\hline OkpotunoOdekpe & 14.0 & 5.0 & 46.0 & 2.2 & 8.5 & 14.6 & 0.01 \\
\hline Atani Road Okoti & 16.0 & 5.7 & 39.0 & 2.2 & 8.7 & 23.7 & 0.00 \\
\hline Okpoko & 10.0 & 2.5 & 60.0 & 2.4 & 12.6 & 12.8 & 0.00 \\
\hline Imeogbe & 4.0 & 6.3 & 45.0 & 2.3 & 10.2 & 62.0 & 0.01 \\
\hline AnibuezeOdekpe & 16.0 & 6.3 & 54.0 & 2.2 & 12.1 & 52.8 & 0.01 \\
\hline WHO Standard & 250 & 0.3 & 100 & 75 & 150 & 250 & 100 \\
\hline
\end{tabular}


Table 4. Chemical characteristics investigated in the borehole water samples in Ogbaru Communities during the wet season

\begin{tabular}{|c|c|c|c|c|c|c|c|}
\hline Borehole location & $\begin{array}{c}\text { Total } \\
\text { Alkalinity } \\
(\mathbf{m g} / \mathbf{l})\end{array}$ & $\begin{array}{c}\text { Total } \\
\text { Acidity } \\
\mathbf{( m g / l}\end{array}$ & $\begin{array}{c}\text { Total } \\
\text { Hardness } \\
(\mathbf{m g} / \mathbf{l})\end{array}$ & $\begin{array}{c}\text { Calcium } \\
\text { Hardness } \\
(\mathbf{m g} / \mathbf{l})\end{array}$ & $\begin{array}{c}\text { Magnesium } \\
\text { Hardness } \\
(\mathbf{m g} / \mathbf{l})\end{array}$ & $\begin{array}{c}\text { Total } \\
\text { Chlorides } \\
(\mathbf{m g} / \mathbf{l})\end{array}$ & $\begin{array}{c}\text { Sulphates } \\
\mathbf{( m g} / \mathbf{l})\end{array}$ \\
\hline Odunze Street Atani & 25.0 & 10.0 & 90.0 & 5.6 & 20.3 & 76.5 & 0.06 \\
\hline AbiriboseAtani & 15.0 & 8.1 & 52.0 & 2.8 & 11.8 & 96.6 & 0.03 \\
\hline UjadimegwuAtani & 17.5 & 22.5 & 65.0 & 3.2 & 15.2 & 81.1 & 0.04 \\
\hline Ochuche & 13.5 & 7.5 & 45.0 & 2.2 & 10.3 & 74.7 & 0.05 \\
\hline Akili-Ozizor & 16.0 & 7.5 & 65.0 & 2.2 & 15.1 & 52.8 & 0.02 \\
\hline Cathedral Road Atani & 35.0 & 10.0 & 80.0 & 8.8 & 17.1 & 87.5 & 0.00 \\
\hline UmunduOhita & 40.0 & 6.3 & 94.0 & 8.8 & 21.7 & 82.9 & 0.06 \\
\hline Odekpe & 18.0 & 7.5 & 80.0 & 5.6 & 17.9 & 90.2 & 0.05 \\
\hline Iyiowa & 16.0 & 5.0 & 50.0 & 3.0 & 11.5 & 69.2 & 0.02 \\
\hline OkotiOdekpe & 17.0 & 5.0 & 48.0 & 1.8 & 11.4 & 90.2 & 0.01 \\
\hline OkpotunoOdekpe & 16.0 & 5.0 & 60.0 & 10.4 & 13.9 & 73.8 & 0.01 \\
\hline Atani Road Okoti & 21.0 & 7.5 & 50.0 & 2.6 & 11.5 & 90.2 & 0.01 \\
\hline Okpoko & 22.5 & 6.3 & 72.0 & 7.6 & 16.8 & 88.4 & 0.01 \\
\hline Imeogbe & 12.0 & 10.0 & 50.0 & 2.4 & 11.4 & 68.3 & 0.01 \\
\hline AnibuezeOdekpe & 18.0 & 7.5 & 60.0 & 3.6 & 13.9 & 90.2 & 0.02 \\
\hline WHO Standard & 250 & 0.3 & 100 & 75 & 150 & 250 & 100 \\
\hline
\end{tabular}

The chemical characteristics investigated in the borehole water samples in Ogbaru communities during the wet season are shown in Table 4 . The total alkalinity values were $12.0-40.0 \mathrm{mg} / \mathrm{l}$; total acidity, $5.0-22.5 \mathrm{mg} / 1$; total hardness, $45.0-94.0 \mathrm{mg} / 1$; calcium hardness, $1.8-10.4 \mathrm{mg} / 1$; magnesium hardness, $10.3-21.7 \mathrm{mg} / 1$; total chlorides, $52.8-96.6 \mathrm{mg} / 1$ and sulphates, $0.00-0.06 \mathrm{mg} / 1$.

Table 5 showed the heavy metals characteristics investigated in the borehole water samples in Ogbaru communities during the dry season. The values for cadmium were $0.01-0.32 \mathrm{mg} / 1$; lead, $0.00-0.08 \mathrm{mg} / 1$; arsenic, $0.00-0.04 \mathrm{mg} / \mathrm{l}$ and iron, $0.00-0.05 \mathrm{mg} / \mathrm{l}$.

Table 5. Heavy metals characteristics investigated in the borehole water samples in Ogbaru Communities during the dry season

\begin{tabular}{|c|c|c|c|c|}
\hline Borehole location & $\begin{array}{c}\text { Cadmium } \\
(\mathbf{m g} / \mathbf{l})\end{array}$ & $\begin{array}{c}\text { Lead } \\
(\mathbf{m g} / \mathbf{l})\end{array}$ & $\begin{array}{c}\text { Arsenic } \\
(\mathbf{m g} / \mathbf{l})\end{array}$ & $\begin{array}{c}\text { Iron } \\
(\mathbf{m g} / \mathbf{l})\end{array}$ \\
\hline Odunze Street Atani & 0.16 & 0.01 & 0.03 & 0.02 \\
\hline AbiriboseAtani & 0.05 & 0.08 & 0.02 & 0.04 \\
\hline UjadimegwuAtani & 0.10 & 0.02 & 0.02 & 0.03 \\
\hline Ochuche & 0.05 & 0.01 & 0.03 & 0.05 \\
\hline Akili-Ozizor & 0.02 & 0.00 & 0.00 & 0.02 \\
\hline Cathedral Road Atani & 0.10 & 0.00 & 0.02 & 0.02 \\
\hline UmunduOhita & 0.10 & 0.08 & 0.02 & 0.03 \\
\hline Odekpe & 0.32 & 0.01 & 0.04 & 0.04 \\
\hline Iyiowa & 0.18 & 0.03 & 0.03 & 0.00 \\
\hline OkotiOdekpe & 0.05 & 0.01 & 0.02 & 0.03 \\
\hline OkpotunoOdekpe & 0.02 & 0.03 & 0.01 & 0.02 \\
\hline Atani Road Okoti & 0.02 & 0.04 & 0.02 & 0.01 \\
\hline Okpoko & 0.01 & 0.02 & 0.02 & 0.03 \\
\hline Imeogbe & 0.12 & 0.02 & 0.00 & 0.03 \\
\hline AnibuezeOdekpe & 0.16 & 0.02 & 0.02 & 0.02 \\
\hline WHO Standard & 0.03 & 0.01 & 0.01 & 0.30 \\
\hline
\end{tabular}

The heavy metals characteristics investigated in the borehole water samples in Ogbaru communities during the wet season are shown in Table 6 . The values for cadmium were from 0.03 to $0.34 \mathrm{mg} / 1$; lead, $0.01-0.20 \mathrm{mg} / \mathrm{l}$; arsenic, $0.00-0.04 \mathrm{mg} / \mathrm{l}$ and iron, $0.02-0.08 \mathrm{mg} / \mathrm{l}$.

Table 6. Heavy metals characteristics investigated in the borehole water samples in Ogbaru Communities during the wet season

\begin{tabular}{|c|c|c|c|c|}
\hline Borehole location & $\begin{array}{c}\text { Cadmium } \\
(\mathbf{m g} / \mathbf{l})\end{array}$ & $\begin{array}{c}\text { Lead } \\
(\mathbf{m g} / \mathbf{l})\end{array}$ & $\begin{array}{c}\text { Arsenic } \\
(\mathbf{m g} / \mathbf{l})\end{array}$ & $\begin{array}{c}\text { Iron } \\
(\mathbf{m g} / \mathbf{l})\end{array}$ \\
\hline Odunze Street Atani & 0.22 & 0.02 & 0.03 & 0.07 \\
\hline AbiriboseAtani & 0.05 & 0.09 & 0.03 & 0.06 \\
\hline UjadimegwuAtani & 0.13 & 0.03 & 0.02 & 0.06 \\
\hline Ochuche & 0.05 & 0.02 & 0.04 & 0.06 \\
\hline Akili-Ozizor & 0.04 & 0.03 & 0.00 & 0.08 \\
\hline Cathedral Road Atani & 0.15 & 0.01 & 0.04 & 0.02 \\
\hline UmunduOhita & 0.19 & 0.20 & 0.04 & 0.04 \\
\hline Odekpe & 0.34 & 0.04 & 0.04 & 0.05 \\
\hline Iyiowa & 0.21 & 0.04 & 0.04 & 0.02 \\
\hline OkotiOdekpe & 0.07 & 0.01 & 0.02 & 0.04 \\
\hline OkpotunoOdekpe & 0.05 & 0.04 & 0.02 & 0.04 \\
\hline Atani Road Okoti & 0.03 & 0.05 & 0.02 & 0.02 \\
\hline Okpoko & 0.11 & 0.03 & 0.02 & 0.05 \\
\hline Imeogbe & 0.17 & 0.04 & 0.00 & 0.04 \\
\hline AnibuezeOdekpe & 0.19 & 0.02 & 0.20 & 0.03 \\
\hline WHO Standard & 0.03 & 0.01 & 0.01 & 0.30 \\
\hline
\end{tabular}




\section{Discussion}

Some of the borehole water samples analysed during both seasons were acidic while others were alkaline. The $\mathrm{pH}$ values of the samples measured during the dry season were 3.4-8.3 and 4.8-8.5 during the wet season (Tables 1 and 2). Twelve $(80 \%)$ and thirteen $(86.7 \%)$ of the boreholes examined during the dry and wet seasons respectively met the World Health Organization standard of 6.5-8.5 for drinking water. Studies on ground water in Wassa West District in the Western Region of Ghana by Kortasi [9] showed a $\mathrm{pH}$ range of 4.5-6.9. However, Onuorah et al.[7] analysed some public hand-pump borehole water in Onueke, Ezza Local Government Area of Ebonyi State, Nigeria and reported a pH range of 7.2-8.8 and 7.5-9.0 during the dry and rainy seasons respectively while Basavaraja et al. [10] and Abdullahi et al. [11] reported $\mathrm{pH}$ values ranging from 7.5-8.4 and 7.51-7.60 for the borehole water samples they analysed. Schaefer et al.[12] reported that low $\mathrm{pH}$ values would make water to be corrosive while Amoako et al.[13] reported that the geology of the soil could account for low $\mathrm{pH}$ values of borehole water in an area.

The temperature values of the borehole water examined were $28-29^{\circ} \mathrm{C}$ and $25-28^{\circ} \mathrm{C}$ during the dry and wet seasons respectively (Tables 1 and 2). All the samples complied with the World Health Organization standard of $25-40^{\circ} \mathrm{C}$ for potable water. This result agreed with Josiah et al.[14] that reported a temperature range of $26-30^{\circ} \mathrm{C}$ for the water samples they analysed. Temperature has been reported to influence the chemical and biochemical characteristics of water [15]. The electrical conductivity values of the samples were $15-238 \mathrm{us} / \mathrm{cm}$ and $41-910 \mathrm{us} / \mathrm{cm}$ during the dry and wet seasons respectively (Tables 1 and 2). The values for both seasons were within the World Health Organization standard of $1000 \mathrm{us} / \mathrm{cm}$. Electrical conductivity is an indicator of water quality and soil salinity. This result conformed to the works of Olusiji et al. [16] and Bernard and Ayeni [17] that reported an electrical conductivity range of $20-750 \mathrm{us} / \mathrm{cm}$ and a mean conductivity value of $135 \mathrm{us} / \mathrm{cm}$ for the water samples they analysed. Lehloesa et al.[18] also obtained an electrical conductivity range of $222-689 \mathrm{us} / \mathrm{cm}$ in the borehole water they analysed in the Victoria District of South Africa.

The values for the total suspended solids were $0.00-0.25 \mathrm{mg} / \mathrm{l}$ during the dry season and $0.03-2.01 \mathrm{mg} / \mathrm{l}$ during the wet season (Tables 1 and 2). The values for both seasons were within the WHO permissible limit of $30 \mathrm{mg} / 1$ for drinking water .Onuorah et al. [7] reported the total suspended solids values of $0.01-0.84 \mathrm{mg} / \mathrm{l}$ and $0.01-0.48 \mathrm{mg} / \mathrm{l}$ during the dry and wet seasons respectively for the borehole water samples they analysed. Onwughara et al.[20] however reported that the total suspended solids of the samples they analysed ranged from $31.3-55.0 \mathrm{mg} / 1$. The total alkalinity of the samples during the dry season were $4.0-27.0 \mathrm{mg} / 1$ while they were $12.0-40.0 \mathrm{mg} / 1$ during the wet season (Tables 3 and 4). The values were within the WHO permissible limit of $250 \mathrm{mg} / \mathrm{l}$. Similar results were obtained by Okoye and Adiele [19] in their physicochemical studies of borehole water samples.

The total acidity of the samples ranged from 2.5 to $7.5 \mathrm{mg} / 1$ during the dry season and 5.0 to $22.5 \mathrm{mg} / 1$ during the wet season (Tables 3 and 4). All the samples examined did not comply with the WHO standard of $0.3 \mathrm{mg} / 1$ for potable water. Taiwo et al. [21] also reported high acidity value of $1.00 \mathrm{mg} / \mathrm{l}$ for the water samples they examined.The values for total hardness during the dry season were $30.0-84.0 \mathrm{mg} / 1$ and $45.0-94.0 \mathrm{mg} / \mathrm{l}$ during the wet season (Tables 3 and 4). All the values were within the WHO standard of $100 \mathrm{mg} / \mathrm{l}$ for potable water. The calcium hardness values were $0.6-3.4 \mathrm{mg} / 1$ during the dry season and $1.8-10.4 \mathrm{mg} / 1$ during the wet season(Tables 3 and 4 ). All the values were within the WHO standard of $75 \mathrm{mg} / \mathrm{l}$ for drinking water.Similar results were obtained by Onuorah et al.[7] who studied the physicochemical characteristics of public hand-pump boreholes in Onueke, Ebonyi State, Nigeria.

The values of magnesium hardness were $6.8-18.0 \mathrm{mg} / 1$ and $10.3-21.7 \mathrm{mg} / \mathrm{l}$ during the dry and wet seasons respectively(Tables 3 and 4). The values were within the WHO permissible limit of $150 \mathrm{mg} / \mathrm{l}$. The results agreed with those of Olusiji et al.[16] who reported a magnesium hardness of $3.4-25.9 \mathrm{mg} / 1$ for the water samples they examined. High levels of magnesium in drinking water will render such water objectionable to consumers and may even become hazardous to health [20].Drinking water with too low magnesium content is also harmful to human health. The minimum value is $10 \mathrm{mg} / \mathrm{l}$.

The total chlorides ranged from 7.3 to $66.5 \mathrm{mg} / 1$ during the dry season and 52.8 to $96.6 \mathrm{mg} / \mathrm{l}$ during the wet season(Tables 3 and 4). All the values were within the WHO permissible limit of $250 \mathrm{mg} / 1$ for potable water. High levels of chlorides make water unfit for drinking by imparting salty taste and may harm metallic pipes [22]. Sulphates ranged from $0.00-0.04 \mathrm{mg} / 1$ and $0.00-0.06 \mathrm{mg} / 1$ during the dry and wet seasons respectively (Tables 3 and 4). The values were within the WHO standard of $100 \mathrm{mg} / \mathrm{l}$ for potable water. Sulphate has been reported to have deleterious effect on young children who are very sensitive to it [23].

The values for cadmium in the samples were $0.01-0.32 \mathrm{mg} / 1$ during the dry season and $0.03-0.34 \mathrm{mg} / 1$ during the wet season (Tables 5 and 6). Four (26.7\%) and one $(6.7 \%)$ of the boreholes examined during the dry and wet seasons respectively complied with the WHO standard of $0.03 \mathrm{mg} / 1$ for potable water. High level of cadmium in water has been linked to lung cancer, kidney diseases and bone defects in humans and animals. The lead content of the samples were $0.00-0.08 \mathrm{mg} / 1$ during the dry season and 0.01-0.20 during the wet season (Tables 5 and 6). Six (40\%) and two $(13.3 \%)$ of the boreholes studied conformed to the WHO standard of $0.01 \mathrm{mg} / 1$ for potable water. High 
concentration of lead in water can cause serious damage to the brain, kidney, nervous system and the red blood cells. The values for arsenic in the samples were $0.00-0.04 \mathrm{mg} / 1$ during the dry and wet seasons (Tables 5 and 6). Three (20\%) and two (13.3\%) of the boreholes analysed complied with the WHO standard of $0.01 \mathrm{mg} / \mathrm{l}$ for drinking water. Arsenic in water is toxic to humans even at low concentration and may originate from agricultural practices or natural arsenic bearing rock [24].

The iron content of the samples ranged from $0.00-0.05 \mathrm{mg} / \mathrm{l}$ during the dry season and $0.02-0.08 \mathrm{mg} / \mathrm{l}$ during the wet season (Tables 5 and 6 ). All the values were within the WHO standard of $0.30 \mathrm{mg} / 1$ for drinking water. Iron at a high concentration can cause transfusional siderosis in the spleen, disturbance in liver functions and diabetes mellitus [25].The values of the physicochemical characteristics of the borehole water studied were relatively higher during the wet that the dry season. This may be attributed to the mild weather conditions prevalent during the wet season and the rain water which may not only had diluted the borehole water source but also introduced some leachates including organic and inorganic matters into the water body.The total hardness, total chlorides, cadmium and arsenic had significant correlation at $5 \%$ significance level using $t$-distribution indicating that they were significantly affected by the seasonal variation.

\section{Conclusions}

This study showed that some of the boreholes sampled did not comply with the standard set by the World Health Organization in terms of $\mathrm{pH}$,total acidity, cadmium, lead and arsenic values and must be treated adequately before use. The use of geophysical method in selecting appropriate locations for ground water development should be encouraged within Ogbaru communities. Government effort should be geared towards the provision of waste disposal infrastructures such as incinerators and waste cycling facilities. In addition, periodic physicochemical analysis of the water from the boreholes in Ogbaru communities to determine their potability is recommended.

\section{REFERENCES}

[1] Hughes, J. M. and Koplan, J. P. (2005). Saving lives through global safe water. Emerging Infectious Diseases. 11(10): 1636-1637.

[2] Kosek, M; Bern, C. and Guerrant, R.L. (2003). The global burden of diarrheal disease, as estimated from studies published between 1992 and 2000. Bulletin of World Health Organization. 81 (3): 197-204.

[3] Adekunle, I; Adetunji, M. T., Gbadebo, A. M. and Banjoko, O.P. (2007). Assessment of ground water quality in a typical rural settlement in South West Nigeria. International
Journal of Environmental Research and Public Health. 4(4): 307-318.

[4] Tredoux, G., Cave, L. and Engelbrecht, P. (2007). Groundwater pollution: Are we monitoring appropriate parameters. Water S.A. 30(5):114-119.

[5] Erah, P. O., Akujieze, C. N. and Oteze, G. E. (2002). The quality of groundwater in Benin City: A baseline study on inorganic chemicals and microbial contaminants of health importance in boreholes and open wells. Tropical Journal of pharmaceutical Research .1 (2): 75-82.

[6] Hogue, B., Hallman, K., Levy, J; Bouis. H., Ali, N; Khan, F; Khanam, S., Kabir, M., Hossain, S. and Alam, M.S. (2006). Rural drinking water at supply and household levels: Quality Management. International Journal of Hygiene and Environmental Health. 209(5): 451-460.

[7] Onuorah Samuel, Nwoke John and Odibo Frederick (2018). Physicochemical studies of Public Hand-pump Borehole water in Onueke, Ezza Local Government Area of Ebonyi State, Nigeria. American Journal of Quantum Chemistry and Molecular Spectroscopy. 2 (2): 31-38.

[8] American Public Health Association (2014). Standard methods for examination of water and wastewater, 20th Edition, American Public Health Association, American Water Works Association and Water Environmental Federation, Washington D.C. Pp 12-15.

[9] Kortatsi, B.K (2009). Ground water quality in the Wassa West District of the Western Region of Ghana. West Africa Journal of Applied Ecology. 11(1):25-40.

[10] Basavaraja, S; Hiremath, S., Murthy, K. N. S; Chandrashekarappa, K. N; Patel, A. N. and Puttiah, E.T. (2011). Analysis of water quality using physicochemical parameters from Hosahalli Tank in Shimoga District, Karnataka, India. Global Journal of Science Frontier Research. 1(3): 31-34.

[11] Abdullahi, M; Saidu, B. T., Salihu, B. A and Mohammed, S. A. (2013). Bacteriological and physicochemical properties of borehole water in Niger State Polytechnic, Zungeru Campus. Indian Journal of Science Research. 4 (1): 1-6.

[12] Schaefer, A, Rossiter, H. M. A., Owusu, P. A., Richards, B.S., and Awuah, E. (2009). Developing country water supplies: physicochemical water quality in Ghana: prospects for water technology information. Desalination .248: 193-203.

[13] Amoako, J., Karikari, A. Y. and Ansa-Asare, O. D. (2011). Physicochemical quality of boreholes in Densu Basin of Ghana. Applied Water Science. 1(1-2): 41-48.

[14] Josiah, J. S., Nwangwu, C. O. S., Omage, K., Akpanyung, O. E. and Amaka, D. D (2014). Physicochemical and microbiological properties of water samples used for domestic purposes in Okada Town, Edo State, Nigeria. International Journal of Current Microbiology and Applied Sciences. 3(6): 886-894.

[15] Manjare, S. A., Vhanalakar, S. A. and Muley, D. V. (2010). Analysis of water quality using physicochemical parameters Tamdalge Tank in Kolhapur district, Maharastra. International Journal of Advanced Biotechnology and Research. 1(2): 115-119.

[16] Olusiji, S. A., Adeyinka, O. A and Adeyinka, A. (2011). Potability status of some hand-dug wells in Ekiti State, 
South Western Nigeria. International Journal of Science and Technology. 1(2): 102-109.

[17] Bernard, E. and Ayeni, N. (2012). Physicochemical analysis of groundwater sample of Bichi Local Government Area of Kano State of Nigeria. World Environment. 2(6):116-119.

[18] Lehloesa, L. J. and Muyima, N. Y. O. (2000). Evaluation of the impact of household treatment procedures on the quality of groundwater supplies in the rural community of the Victoria District, Eastern Cape. Water SA. 26(2):285-290.

[19] Okoye, C. O. B. and Adiele, G. C. (2014). Physicochemical and bacteriological qualities of groundwater resources in EzinihiteMbaise Local Government Area of Imo State, Nigeria. International Journal of Chemical Science. 12(1): 23-38.

[20] Onwughara, N. I., Ajiwe, V. I. E. and Nnabuenyi, H.O. (2013). Physicochemical studies of water from selected boreholes in Umuahia North Local Government Area in Abia State, Nigeria. International Journal of Pure and Applied Bioscience. 1(3):34-44.

[21] Taiwo, A. A; Ijaola, T. O., Oluwadare, I. and Osunkiyesi, A. (2012). Physicochemical and bacteriological analysis of well water in Abeokuta Metropolis, Ogun State, Nigeria. IOSR Journal of Applied Chemistry. 2(6):29-35.

[22] Barati, A. H., Maleki, A. and Alasvand, M. (2010). Multitrace element level in drinking water and the prevalence of multichronic arsenical poisoning in residents in the west area of Iran. Science of the Total Environment. 408(7):1223-1233.

[23] Olajubu, F. A. and Ogunika, F. (2014). Assessment of the physicochemical and microbiological properties of borehole water samples from Akungba-Akoko, Ondo State, Nigeria. International Journal of Pharma Science and Research. 5(7):367-374.

[24] Smedley, P. L. and Kiniburgh, D. G. (2002). A review of the source, behaviour and distribution of arsenic in natural waters. Applied Geochemistry. 17(5): 517-568.

[25] Klaaseen, D. C., Amodur, O. M. and Doull, J. (1986). The basic science of poisons. $3^{\text {rd }}$ edition, MacMillan Publishing Company, New York. Pp 592-596. 